\title{
Effect Of Crumb Rubber On Compressive Strength Of Fly Ash Based Geopolymer Concrete
}

\author{
Ahmad Azrem Azmi ${ }^{1, *}$, Mohd Mustafa Al Bakri Abdullah ${ }^{2,3}$, Che Mohd Ruzaidi Ghazali ${ }^{2,1}$, \\ Andrei Victor Sandu ${ }^{4,3}$, and Kamarudin Hussin ${ }^{2,1}$ \\ ${ }^{1}$ Center of Excellence Geopolymer and Green Technology, School of Materials Engineering, \\ Universiti Malaysia Perlis (UniMAP), 01007, P.O Box 77, D/A Pejabat Pos Besar, Kangar, Perlis, \\ Malaysia. \\ ${ }^{2}$ Faculty of Engineering Technology, Universiti Malaysia Perlis (UniMAP), 01007, P.O Box 77, D/A \\ Pejabat Pos Besar, Kangar, Perlis, Malaysia. \\ ${ }^{3}$ Faculty of Technology, UniversitasUbudiyah Indonesia (UUI), JlnAlue Naga DesaTibang, Banda \\ Aceh, Indonesia \\ ${ }^{4}$ Gheorghe Asachi Technical University of lasi, Faculty of Materials Science and Engineering, Blvd. \\ D. Mangeron 71, 700050, lasi, Romania
}

\begin{abstract}
This study explores the effect of different percentage of crumb rubber on compressive strength of fly ash based geopolymer concrete. This research attempted to produce rubberized geopolymer concrete as an environmentally friendly, lightweight and durable product. Crumb rubber with ranged size from $73 \mu \mathrm{m}$ to $375 \mu \mathrm{m}$ was used in order to replace fine aggregates in geopolymer concrete. The replacements of crumb rubber were $0 \%, 5 \%, 10 \%, 15 \%$ and $20 \%$ in the fly ash based geopolymer concrete. The ratio of fly ash to alkaline activator was 2.5 and the ratio of $\mathrm{Na} 2 \mathrm{SiO} 3$ to $\mathrm{NaOH}$ was fixed at 2.0. After the curing process, the strengths of the samples were tested on days 7 and 28 . The results show that there is a reduction in all compressive strength for crumb rubber mixture, but still higher than normal rubberized concrete. Rubberized geopolymer concrete is a suitable solution in some non structural applications.
\end{abstract}

\section{Introduction}

Geopolymer is known for its durability and environmental sustainability. Sustainable practice of industrial ecology demands the use of byproduct of one industry as source materials for other industrial application. This will help in complying with environmental parameters for both the industry. Environmental concerns compelled us to reduce the material consumption by enhancing the durability and resource efficiency using advanced technology [1-2]. In general, geopolymers as a class of inorganic polymer are formed by reaction between an alkaline solution (e.g., sodium hydroxide and sodium silicate) and an aluminosilicate source (e.g., metakaolin, fly ash, and slag) [3]. Geopolymer or alkali-

*Corresponding author: mustafa_albakri@unimap.edu.my 
activated binder is produced by activating aluminosilicate source materials with highly alkaline activator solution at ambient or high temperature. A highly alkaline solution such as sodium hydroxide $(\mathrm{NaOH})$ and sodium silicate $(\mathrm{Na} 2 \mathrm{SiO} 3)$ was usually used as alkaline solution [4-5].

Fly ash normally produced from burning anthracite or bituminous coal that meets the applicable requirements for this class. This class of fly ash has pozzolanic properties [6]. Fly ash is suitable for use as a geopolymer source material because it consists mostly of glassy, hollow and spherical particles. Fly ash-based geopolymer cement and concrete have been studied extensively, and they are well known for their properties, which are better than those of normal concrete due to their lower creep, lower shrinkage, better fire and acid resistance, and resistance to sulfate attack [7].

Geopolymer concrete is concrete which does not utilize any Portland cement in its production. Geopolymer concrete is being studied extensively and shows promise as a substitute to Portland cement concrete. Research is shifting from the chemistry domain to engineering applications and commercial production of geopolymer concrete [8]. Producing a typical car tyre uses about $40 \%$ natural rubber and $60 \%$ synthetic rubber that needs to be separated from the tyre's steel casing before it can be used as a rubber crumb. The products obtained from scrap tyres are classified as whole scrap tyres, slit tyres, shredded/chipped, ground and rubber crumb. Rubber crumb particle sizes range between $4.75 \mathrm{~mm}$ to less than $0.075 \mathrm{~mm}$ [9] and are irregularly shaped, torn particles due to the micro-mill process, they are subjected to during the manufacturing process [10-12]. The recycling will reduce the waste and contribute to a greener environment.

Over the past few years, a number of researchers have studied on incorporated the waste tires into cement based materials [13-18]. However, this paper presents the study of early age, strength of geopolymer concrete with recycled rubber. This study used crumb rubber as an aggregate to produce rubberized geopolymer concrete. By using rubber waste to produce lightweight geopolymer concrete is expected to more durable, less expensive (low material cost and easy to manufacture) and absorb higher energy under impact [19].

\section{Raw materials}

In this experiment, crumb rubber from automotive and truck scrap tires, in order to replace fine aggregates. It has particles ranging from $73 \mu \mathrm{m}$ to $375 \mu \mathrm{m}$. Crumb rubber has a lower unit weight compared to mineral aggregates. The addition of crumb rubber to the mixture reduced the unit weight of the geopolymer concrete mixture. The replacements of crumb rubber in the mixture were $0 \%, 5 \%, 10 \%, 15 \%$ and $20 \%$.

Table 1. The composition of fly ash.

\begin{tabular}{|c|c|}
\hline Elements & \% mass \\
\hline $\mathrm{Al}_{2} \mathrm{O}_{3}$ & 23.40 \\
$\mathrm{SiO}_{2}$ & 50.00 \\
$\mathrm{SO}_{3}$ & 0.08 \\
$\mathrm{~K}_{2} \mathrm{O}$ & 1.41 \\
$\mathrm{CaO}$ & 5.06 \\
$\mathrm{TiO}$ & 1.60 \\
$\mathrm{MnO}_{2}$ & 0.22 \\
$\mathrm{Fe}_{2} \mathrm{O}_{3}$ & 17.29 \\
\hline
\end{tabular}

Low calcium class F fly ash (ASTM Class F) used in this research was obtained from the Sultan Abdul Aziz Power Station in Kapar, Selangor, Malaysia. It was used as a source 
material in the geopolymer concrete mixture. Table 1 shows the composition of fly ash, as determined by X-Ray Fluorescence (XRF).

The brand named Formosoda-P of sodium hydroxide $(\mathrm{NaOH})$ powder with pure $99 \%$ was obtained from the Formosa Plastic Corporation, Taiwan used to produce the $\mathrm{NaOH}$ solution. Sodium silicate (Na2SiO3) with chemical composition of $30.1 \% \mathrm{SiO} 2,9.4 \%$ $\mathrm{Na} 2 \mathrm{O}$ and $60.5 \% \mathrm{H} 2 \mathrm{O}$ (modulus, $\mathrm{SiO} 2 / \mathrm{Na} 2 \mathrm{O}=3.2$ ) was obtained from South Pacific Chemicals Industries Sdn. Bhd. (SPCI), Malaysia. It has a specific gravity at $20{ }^{\circ} \mathrm{C}=1.4$ $\mathrm{g} / \mathrm{cm} 3$ and viscosity at $20^{\circ} \mathrm{C}=0.4 \mathrm{~Pa}$.

\section{Mixing methode}

In order to produce $12 \mathrm{M} \mathrm{NaOH}$ solution [20], $480 \mathrm{~g}$ of $\mathrm{NaOH}$ powder were dissolved in 1 $\mathrm{L}$ distilled water and allowed to cool down at room temperature. The alkaline activator was prepared by combining of $\mathrm{NaOH}$ and $\mathrm{Na} 2 \mathrm{SiO} 3$ one day prior to use. The ratio of $\mathrm{Na} 2 \mathrm{SiO} 3$ to $\mathrm{NaOH}$ was fixed at 2.0. The ratio of fly ash to alkaline activator was 2.5 and was kept fixed for all mixtures. Crumb rubber and fly ash were mixed in a dry state for 30 seconds, then alkaline activator were mixed into the mixtures using a hand mixer for another 10 minutes.

\section{Casting and curing}

The mixture of crumb rubber and fly ash were mixed well with alkaline activator for 10 minutes using a hand mixer, forming a homogeneous mortar. The fresh geopolymer paste filled crumb rubber were poured into $50 \mathrm{~mm}$ cube moulds and compacted as described in ASTM C109. The samples were sealed with a thin plastic layer to prevent moisture loss and left cured at room temperature (open air) before demoulding.

\section{Testing}

\subsection{Compressive strength test}

Compressive strength test of geopolymer mortar was performed using GoTech Universal testing Machine according to ASTM C 109/C. Three samples of each percentage of crumb rubber were tested at 7 and 28 days.

\section{Result and discussion}

Table 2 and Figure 1 shown the compressive strength of the rubberized geopolymer concrete decreased with increasing crumb rubber content. The addition of crumb rubber in rubberized geopolymer concrete weakened the compressive strength of rubberized geopolymer concrete. As expected, the higher the crumb rubber content in the mix, the higher the reduction in compressive strength. 


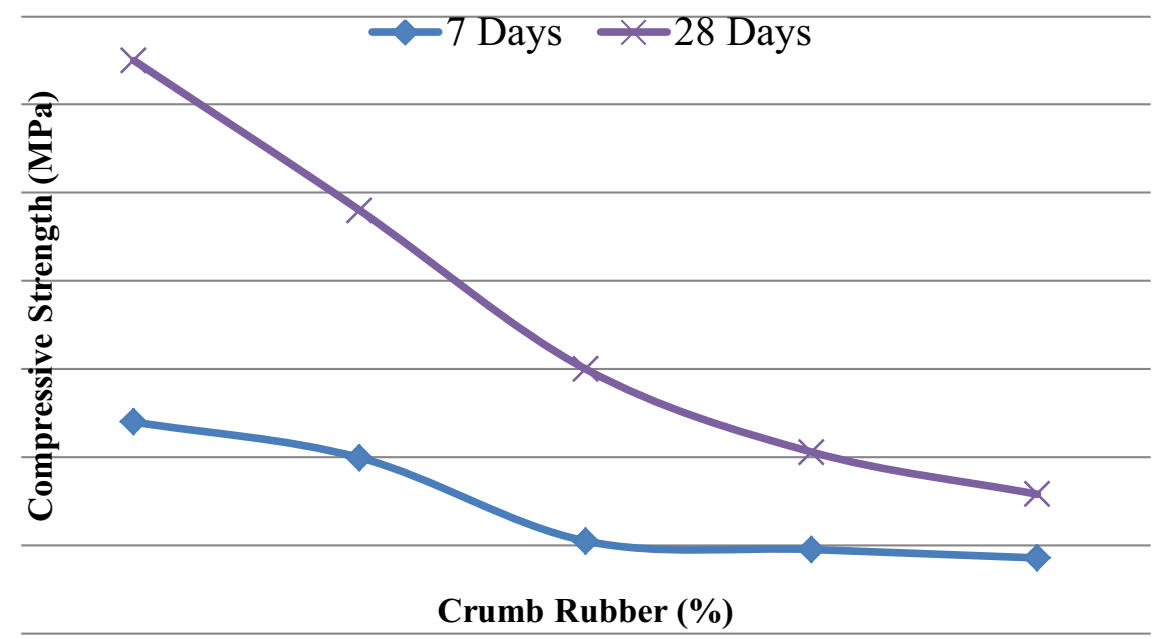

Fig. 1. Compressive strength of rubberized geopolymer concrete at 7 and 28 days.

Table 2. Compressive strength of the rubberized geopolymer concrete at 7 and 28 days.

\begin{tabular}{|c|c|c|c|}
\hline \multirow{2}{*}{ Mix } & \multirow{2}{*}{$\begin{array}{c}\text { Rubber } \\
\%\end{array}$} & \multicolumn{2}{|c|}{ Compression strength(N/mm2) } \\
\hline & & 7 Days & 28 Days \\
\hline 1 & 0 & 24.0 & 65.0 \\
\hline 2 & 5 & 20.0 & 48.0 \\
\hline 3 & 10 & 10.5 & 30.0 \\
\hline 4 & 15 & 9.5 & 20.6 \\
\hline 5 & 20 & 8.5 & 15.8 \\
\hline
\end{tabular}

The performance of rubberized geopolymer concrete is quite encouraging up to $15 \%$. The compressive strength of the rubberized geopolymer concrete decreases about $60 \%$ when $15 \%$ crumb rubber was added. The results of compressive strength of rubberized geopolymer concrete mixtures are affected by the size, proportions, and surface texture of rubber particles, and type of cement used in such mixtures [19]. This is due to the increased porosity or weakness points in the geoploymer concrete mix which is lack of bonding between crumb rubber and fly ash with alkaline activator and lead to high internal stress that are perpendicular to the direction of applied load [21]. With the increase in void content of the concrete, there will be a corresponding decrease in strength. In addition, the failure of the samples also due to the crumb rubber being more elastically deformable than the matrix. The cracks begin at the softest areas when the samples were loaded. The site of the inclusion of rubber is where these sites appear [19].

\section{Conclusion}

The test results of this study show that crumb rubber can be added in geopolymer concrete without any difficulties. With the addition of the crumb rubber, the reduction in strength cannot be avoided. The compressive strength of the rubberized geopolymer concrete decreases about $60 \%$ when $15 \%$ crumb rubber was added. For large amount of crumb rubber in the mixture, the compressive strength gain rate is lower than ordinary concrete. Although compressive strength reduction occurred due to the amount of crumb rubber in 
the geopolymer concrete, these concrete still can be utilized in many engineering applications.

A special thanks to the Center of Excellence Geopolymer and Green Technology (CEGeoGTech) and the School of Materials Engineering, Universiti Malaysia Perlis (UniMAP) for providing research facilities and technical assistance for their help and cooperation in research work.

\section{References}

1. A. Bhowmick, S. Ghosh, Int. J. Eng. Res. Appl., 3(1), 168 (2012)

2. J.T. Gourley, Journal of the Australian Ceramics Society, 50(1), 102 (2014)

3. J. He, Synthesis and Characterization of Geopolymers for Infrastructural Applications, $\mathrm{PhD}$ Thesis, Nottingham University, 2005

4. Z. Yahya, A.M.M. Al Bakri, H. Kamarudin, I. Khairul Nizar, A.R. Razak, Materials Science Forum, 803(2014)

5. M.M.A. Abdullah, K. Hussin, M. Bnhussain, K.N. Ismail, W.M.W. Ibrahim, Int. J. Pure Appl. Sci. Technol., 6(1), 35, 2011

6. M.M. Al Bakri, H. Mohammed, H. Kamarudin, I.K. Niza, Y. Zarina, Journal of engineering and technology research, 3(1), 1(2011)

7. Abdullah, M. M. A. B., Hussin, K., Bnhussain, M., Ismail, K. N., Yahya, Z., Abdul Razak, R., Int. J. Mol. Sci., 13(6), 7186 (2012).

8. S. Jaydeep, B.J. Chakravarthy, International Journal of Engineering Trends and Technology, 4(10), 4614 (2013)

9. S.D. Parveen, A. Sharm, International Journal of Emerging Technology and Advanced Engineering, 3(3), 192 (2013)

10. A. Richardson, K. Coventry, U. Dave, J. Pienaar, Journal of Green Building, 6(1), 83 (2011)

11. H. Maraghechi, I. Fotovat Ahmadi, S. Motahari, J. Mech. Mater. Struct., 6(9), 1283 (2012)

12. K.M. Kotresh, M.G. Belachew, International Journal of Scientific Engineering and Technology, 3, 433 (2014)

13. I.B. Topcu, Cement and Concrete Research, 25(2), 304 (1995)

14. H.A. Toutanji, Cem. Concr. Compos., 18(2), 135 (1996)

15. A. Benazzouk, O. Douzane, T. Langlet, K. Mezreb, J.M. Roucoult, M. Queneudec, Cem. Concr. Compos., 29(10), 732 (2007)

16. S. Sgobba, G.C. Marano, M. Borsa, M. Molfetta, $2^{\text {nd }}$ International Conference on Sustainable Construction Materials and Technologies, 2010

17. A.A.Yasin, Contemporary Engineering Sciences, 5(10), 473 (2012)

18. Y. Park, A. Abolmaali, P. Aswath, S.Lee, The 2015 World Congress on Advanced in Structural Engineering and Mechanics, 2015

19. M.M.A.B. Abdullah, S.N.F.S. Adam, M.A. Bakar, K.W. Leong, Proceedings of the $1^{\text {st }}$ International Conference On Sustainable Materials, 2007

20. A.M. Al Bakri, H. Kamarudin, M. Bnhussain, I.K. Nizar, A.R. Rafiza, Y. Zarina, Rev. Adv. Mater. Sci., 30, 90 (2012)

21. P. Nithiya, G. Portchejian, International Journal of Structural and Civil Engineering Research, 3(3), 63 (2014) 